\title{
Editorial
}

\section{A Central European Face of Criminology and Rehabilitation - Processes, Changes and Problems}

\author{
J. Martin Ramirez ${ }^{1, *}$ and Marzanna Farnicka ${ }^{2}$ \\ ${ }^{I}$ Center for Conflict Studies, Nebrija University, Madrid, Spain \\ ${ }^{2}$ University of Zielona Góra, Poland
}

We live in a world of phenomena created by human mind and experience. Some of them are: conflict, aggression, and violence. They are seen as constructs of the mind, types of behaviour, particular experiences and emotional states, specific social interactions or even historical and political categories regarded as non-standard events (social movements, wars, angry social protests, etc.). Their ambiguity and complexity have not remained unnoticed by Camilla Pagani (2014). Such a broad, imprecise understanding of these notions partly explains their overuse in the analysis and elucidation of social life. The alleged commonness and surface knowledge of the issue stems out of the insufficient diversification of these terms, their improper understanding and, consequently, often inadequate reacting to their symptoms. Martin Ramirez, during his opening words of the XXXVII International Conference on Conflict and Aggression (2014), mentioned that despite the fact that the Seville Statement on Violence was recognised by the UNESCO in 1989 as our heritage, there exist a number of areas of social life where the knowledge of the conditions and prophylactics of aggression as well as good practice in this field are ignored and omitted; one of them sometimes is criminology.

These findings have been recently confirmed by the participants of the above mentioned XXXVII CICA International Conference on Conflict and Aggression: Developmental and Social Conditions, held in Poland on the initiative of CICA, Kazimierz Wielki University and the University of Zielona Góra (21-25 June 2014). Since 1983, the CICA had organised as many as 36 previous international meetings, with past venues scattered across America, Europe, Africa, and Asia. The XXXVII CICA Conference was held in the western Polish city of Zielona Góra. The main topics of the Conference focused on the study of the phenomena of aggression and conflict resolution using a comprehensive, integrated and interdisciplinary approach which takes into account both biological and psycho-sociocultural factors. Various types of conditioning of aggression and violence, methods to measure readiness for aggression

*Address correspondence to this author at the Pico de la Pala 6, 28792 Miraflores (Madrid), Spain; Tel: 3491 8444685; Fax: 349185920 76; E-mail: mramirez@ucm.es and practical implications to be used by specialist in different life environments were analysed.

During a symposium entitled Crime, Victimisation, Prison and Way of Rehabilitation, participants pointed out at the difficulties in various spheres of science and social practice connected with criminology, relating to: the perpetrators and the prison system, the rudimental issues such as understanding accounts of aggression, its genesis, mechanisms, prevention and possibilities of resocialization / rehabilitation. They also indicated some difficulties from the field of criminology encountered by researchers at the initial stage of forming the issue, such as lack of social consent for exploring some contents tackling violence and aggression in various environments. Further difficulties are connected with the creation of research procedures or therapeutic programmes or repair programmes. Their causes stem from ethical and ideological reasons, as well as ignorance (insufficient knowledge among the so-called 'general public' or/and 'decision-makers', disregard for scientific knowledge), economic reasons, political motives, or allegations of their low usefulness and little benefit (both financial and social). And we should also consider that our understanding and prevention of criminal behavior might also be enhanced by a deeper knowledge of the core basic elements of functional and dysfunctional expertise, like the one that offenders might display through practice in a particular criminal domain (Nee \& Ward, 2015).

This special issue is focused to Middle European criminology because, as in other post-Soviet countries, it has been undergoing deep reforms for the past 20 years. Some of these reforms are focused on changing the image and methods of work. The transformation is seen in the use of force, and total and financial solutions. There is a noticeable shift towards searching for social and cultural determinants of perpetrated acts through the application of the so-called soft interactions (Hołyst, 2011). The transformations are visible not only in the manner of conducting investigation, awarding punishment, recruiting staff for the police and prison service, but also in the large focus placed on broadly understood prevention as well as primary, secondary and tertiary rehabilitation (Tyszkiewicz, 2008). An effect of these transformations in the prison system is, for example, the 
recruitment of personnel with a pedagogical (rather than exclusively police and legal) background. Furthermore, it must be emphasized, attention is paid not only to the material conditions provided to convicts but also to the general climate of interpersonal relations from the time of detaining a suspect, through the trial and period spent in a penitentiary institution, up to the return and re-adaptation to society. The so-called Mother and Child Homes have been established for convicted mothers with small children, and a system of probation for prisoners' families has been put into operation. At present, Central European criminology faces the challenge of finding a balance between sociocultural methods and hard evidence supplied by neurobiological sciences. One example is the abolition of capital punishment and the adoption of the maximum prison sentence of 25 years on the one hand, and the problem of surveillance of serial murderers who are released from prison on the other. It represents a specific Foucauldian dilemma between punishment and surveillance under conditions of economic transformations, scientific achievements and limited financial resources (Foucault, 1998).

Some of Foucault's considerations concerning the biological grounds for developmental opportunities and the functioning of people aroused controversies which made some of his concepts contemporarily omitted. It is a controversial proposal to differentiate people based on features independent of them (genetic basis) and underestimating social elements that influence the development of individuals, their free will, decisions and choices. The concerns of the specialists and the so-called decision-makers stem from history which abounded in cases when the knowledge of biological/genetic-based differences within our species was overused for justifying a different treatment of such individuals or implementing different laws. Such dilemmas are inexistent for court experts who use all available data (genetic, medical, results of psychological tests) to minimize the risk of erroneous decisions and conclusions (some of them make use of the "hidden" information (gender, age, DNA code, history of the family, etc.)). The present study is an outline of the current discourse in the field of correctional psychology which can be observed in young EU member states from Central Europe (countries of the post-Soviet bloc).

The Polish penitentiary system has a population of eighty thousand prisoners. In accordance with data collected by the Central Board of the Prison Service, in 2014 the number of the arrested, and also of the convicted: for homicides amounted to more than five thousand, for armed robberies and extortion rackets - to more than twelve thousand, for crimes against public security - to more than five thousand as well, for bullying - to another five thousand and for belonging to organized criminal groups, including also the armed ones - to nearly one thousand (Piotrowski \& Królikowska, 2012). These data give rise to the conclusion that nearly a half of the imprisoned have committed crimes involving aggression and violence. Approximately 200 of the prisoners annually are qualified as 'dangerous'; the definition, in accordance with the Criminal Executive Code, includes 'convicts posing a serious threat to the society, or a serious threat to the security of a penitentiary facility ${ }^{\text {. Every }}$ year, approximately 150 physical assaults on the penitentiary personnel are recorded. No one records incidents of offensive and rude behaviour any more. Drawing up the picture of the population of the imprisoned, one cannot forget about international gangs, people sentenced for terrorism, perpetrators of kidnapping for ransom, professional killers, and also contract killers, who constitute signum temporis, and who are a challenge to the contemporary penitentiary system (Edens, \& Ruiz, 2009). The need to adjust the penitentiary system to the changing population of the imprisoned has resulted, among others, in appointing the permanent Interventional Groups of the Prison Service by the Director-General of the Prison Service (Piotrowski \& Poklek, 2012).

Results of scientific research on the activities of the Prison Service in Poland are rarely published in professional literature. This fact is thought-provoking, as the occupation in the Prison Service has its own distinctive character. Any prison is a total institution, and rules governing its daily activity do not always meet the needs of both prisoners and their guards. Consequently, an accumulation of potential and real emergencies (threats, disturbances, conflicts, strains) may occur, resulting in frustration and occupation-related stress, which in turn can lead to an increase in aggression level and provoke aggressive behaviours.

The present top hot issue of The Open Criminology Journal aims to present Czech and Polish research in the field of criminology and the problems encountered in area connected with changes. It is an attempt to join the global discussion on creating conditions and key points connected with the risk of personality and behaviour pathologization from an individual and social perspective. This issue contains four articles and has been divided into three sections.

In the first section, the Czech psychologist Simona Musilova presents the analysis of the situation in the Czech Republic regarding the general perception of delinquency, co-existence with people of a different nationality, the tendency to become offender or victim. There are many problems connected with the social exclusion of other nationality representatives, and these problems lack obvious solutions. Some of them are caused by locally increased crime rates of minorities coupled with greater rates of victimization.

The second section of the issue presents two articles devoted to research on prison service in Poland. More specifically, the texts published in this section deal with determining factors for perpetrator-type aggressive behaviour among prison functionaries. The first article, entitled Prison Staff Aggression and its Determinants, deals with aggressive behaviour of prison staff - an issue of significant cognitive and pragmatic importance, as well as with the factors influencing the level of such aggression. The authors Jerzy Herberger and Ernest Magda, have assumed that aggression and its symptoms increase along with dysfunctionality of the family environment and the level of occupational stress, and the level of occupational stress rises with dysfunctionality of the family environment.

In the second article of this second section, Marzanna Farnicka focuses on an educational system for the future 
prison staff chiefly based on a dedicated university course, i.e. rehabilitation. The paper presents differences between students and problems arising from their inherent properties, such as greater readiness for aggression and approval of aggression. The results obtained indicate different determinants for persons involved in perpetration or victimization and for those displaying low levels of such behaviour. It was assumed that people majoring in rehabilitation would more often assume the role of an aggressor or a victim than students majoring in other disciplines. Research findings were supposed to contribute to developing a prevention model among students and other people working in the field of violence and violence handling, as well as to emphasise the need to reflect upon and possibly change personal attitudes towards these behaviours.

The special issue concludes with the presentation by Anna Napadło of activities of the Patronat Penitentiary Association established with the aim to help those who are left behind, i.e. prisoners' children. Over the past 15 years, the Association members have been helping families (mainly wives and children) of detainees. This article describes what is being done and what should be done to help people who found themselves in such a situation and presents the most common problems of families who are trying to maintain the bonds of closeness in spite of walls and barriers.

We would like to thank all the authors and their reviewers for the opportunity they have offered us to engage in a discussion in that field and also the Editorial Board of the Open Criminology Journal for a chance of its presentation. We hope this top hot issue will offer you a review of current issues and solutions in the field of criminology-related research in Central European countries, with a more specific focus on correctional psychology. Its contents reveal numerous barriers and differences resulting not only from the geographical location and history of that region but also from a specific approach to that field of study.

\section{REFERENCES}

Edens, JF. \& Ruiz, MA. (2009). Predicting institutional aggression by defensive prison inmates: An examination of the personality assessment inventory treatment consideration scales. The International Journal of Forensic Mental Health, 8(3), 178-185.

Farnicka, M. (2015) Why is it Difficult to Oust Violence from Correctional Institutions?, The Open Criminology Journal, 8(1), 19-23.

Foucault, M. (1998). Surveiller et punir, Warszawa: Aletheia.

Herberger, J. \& Magda, E. (2015), Prison Staff Aggression and its Determinants The Open Criminology Journal, 8(1), 12-18.

Hołyst, B. (2011). Cultural victimology, Studia Prawnicze $i$ Administracyjne, nr 2, pp. 75-86.

Musilova, S. (2015), The Delinquency of other Nationality Representatives in the Czech Republic as part of the Central-East European Region), The Open Criminology Journal, 8(1), 4-11.

Napadło, A. (2015) Family across Prison Walls: A Different Perspective on Incarceration. The Open Criminology Journal, 8(1), 24-27.

Nee, C. Ward, T. (2015). Review of expertise and its general implications for correctional psychology and criminology. Aggression and Violent Behavior 20, 1-9.

Piotrowski, A., Królikowska, I. (2012). Security of penitentiary institution, In: Piotrowski, A. (Eds.), Education for security. Special services in the state security system. Practical aspects of security (pp. 305318). Poznań: Wydawnictwo Wyższej Szkoły Bezpieczeństwa.

Pagani, C. (2014). Violence and Complexity, In: Pagani C, Farnicka M., Liberska H. \& Ramirez M. (Eds) Conflict and Aggression, p.100. Warszawa: Difin,

Piotrowski, A., Poklek, R. (2012). The Safety of Functionaries in the Special Units of Prison Service and its Influence on Family Life, In: Matis, J. Sipko, A. (Eds.), Equal opportunities and reconciliation of work and family in modern organizations (pp. 167-173). Liptovský Mikuláš: Akadémia ozbrojených síl gen. Milana R. Štefánika.

Ramirez, M. (2014). Opening lecture, XXXVII CICA, Poland: Zielona Gora

(C) Ramirez and Farnicka; Licensee Bentham Open.

This is an open access article licensed under the terms of the Creative Commons Attribution Non-Commercial License (http://creativecommons.org/licenses/ by-nc/3.0/) which permits unrestricted, non-commercial use, distribution and reproduction in any medium, provided the work is properly cited. 